IRA-International Journal of Management \& Social Sciences

ISSN 2455-2267; Vol.04, Issue 01 (2016)

Institute of Research Advances

http://research-advances.org/index.php/RAJMSS

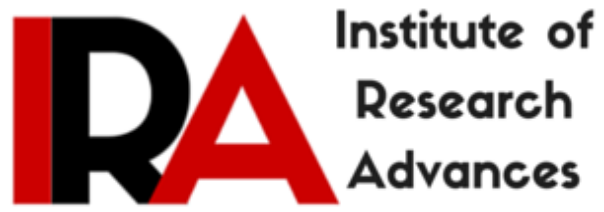

\title{
Influence of Pharma CRM \& Personal Selling Strategies on the Prescription Behaviour of Doctors- A Literature Review
}

\author{
Ms. Gurpreet Kaur ${ }^{1}$ and Dr. Deepali Saluja ${ }^{2}$ \\ ${ }^{1}$ Research Scholar,Department of Management, \\ Mewar University, Chittorgarh, Rajasthan, India. \\ ${ }^{2}$ Research Supervisor and visiting faculty, Department of Management, \\ Mewar University, Chittorgarh, Rajasthan, India.
}

DOI: http://dx.doi.org/10.21013/jmss.v4.n1.p8

\section{How to cite this paper:}

Kaur, G., \& Saluja, D. (2016). Influence of Pharma CRM \& Personal Selling Strategies on the Prescription Behaviour of Doctors- A Literature Review. IRA-International Journal of Management \& Social Sciences (ISSN 2455-2267), 4(1). doi:http://dx.doi.org/10.21013/jmss.v4.n1.p8

(C) Institute of Research Advances

\section{(cc) EY-NC}

This works is licensed under a Creative Commons Attribution-Non Commercial 4.0 International License subject to proper citation to the publication source of the work.

Disclaimer: The scholarly papers as reviewed and published by the Institute of Research Advances (IRA) are the views and opinions of their respective authors and are not the views or opinions of the IRA. The IRA disclaims of any harm or loss caused due to the published content to any party. 


\section{ABSTRACT}

A major aspect of promotional strategy adopted by the Pharma firms in India, has been, personal selling through medical representatives (MRs). However from last few years particularly after the introduction of product patent regime in 2005, market scenarios started changing drastically. To add to the trouble of Pharma marketers, in a development in July 2012 the Indian Pharma companies agreed in principle to enforce a code that will restrict them from offering gifts or other SOPS to doctors. This has resulted in changes in the level,intensity and parameters of competition. MRs who earlier acted as the backbone for the Indian Pharma sector, are finding it very hard to compete, and to make every interaction with doctors, count. Today the Pharma companies that leverage technology solutions such as ERP, CRM, mobility solutions, only have the scope of survival in future. Pharmaceutical companies are gradually realizing that they can no longer afford to be only product or market focused. They have to focus now on relationship marketing or customer relationship management (CRM) in order to gain a complete understanding of their current and potential customers. By implementing CRM, not only the efficiency of sales and marketing efforts increase, but also customer's experience and loyalty towards the pharmaceutical company is enhanced. This research paper presents a review of some of the selected papers and analyzes the factors that influence the prescription behaviour of doctors and tries to evaluate the effects of CRM and personal selling strategies of Pharma companies on this prescription behaviour .

Key words: Medical Representatives (MRs), Prescribers (Doctors), Prescription behavior, Pharma CRM, NPPP, IPA, OPPI, IDMA

\section{INTRODUCTION}

The Indian Pharmaceutical Industry that was practically non-existent in early1970's, came into focus when India took over as the primary center for pharmaceutical production of bulk drugs and products without patent production. It's a highly fragmented market and the top 10 pharmaceutical companies account for only $35-40 \%$ of the market. There are over 10,000 pharmaceutical companies in India. $\left(D^{\prime}\right.$ Souza Ajay,2012). The Indian pharmaceutical industry currently valued at 72069 crore INR ranked $3^{\text {rd }}$ largest in terms of volume and $14^{\text {th }}$ in terms of value, in global pharmaceutical market business. (Shah Viral,2012)The Indian Pharma industry has been growing at a compounded annual growth rate (CAGR) of more than $15 \%$ over the last five years but the market experienced a slowdown in the financial year 2013-2014 and its growth has gone down to $9.8 \%$ from $16.6 \%$ in 2012(pharmaceutical industry update 2012). This slow down can be attributed to the new drug pricing policy and the regulatory interventions over the last year(Pharma summit,2013). Presently, India is considered as one among the top five pharmaceutical emerging markets of the world. India has established itself as a big mart of the pharmaceutical industry(Brute Gert,2011). The Indian pharmaceutical market is predicted to grow from USD 12.6 million in 2009 to USD 55 billion by 2020 and India will join the group of top 10 global pharmaceutical markets in terms of sales by 2020 with the total value reaching USD 50 billion by than (Mc Kinsey report, 2013)

On $1^{\text {st }}$ January 2005, Indian Pharmaceutical industry aligned itself to the global standards due to the enactment of an amendment to 'India's patent law', this change was considered highly significant because the amendment came after a gap of 33 years (India's patent law was introduced in 1972). This move was initiated in line with the WTO's Trade Related Aspects Of Intellectual Property Rights (TRIPS) agreement, which mandated protection on both products and processes for a period of 20 years. To add to this intensifying competitive scenario, potential regulatory interventions could hurt pricing in long run and to top it the introduction of product patent regime [The Indian Patents (Amendment) act 2005] will significantly reduce the basket of products available for introduction.(Sharma Shashi, 2007). Despite of all the challenges Indian Pharmaceutical industry is all set to score new heights in the near future. The top 10 Pharma companies of India have contributed to $41 \%$ of total Indian Pharma market, which is higher 
than its contribution of $39 \%$ in 2010 and these companies had a collective growth of $9 \%$ that is lower than the growth of Indian Pharma market ( $P w C$ study,2013). There has been a slowdown in the growth of the top Indian as well as Multinational companies. However, the slowdown is more prominent in the MNCs than in the Indian companies. In Pharma marketing sector in India, each type of firm has its own marketing strategy. While MNCs take on a more aggressive outlook towards Indian market due to changing marketing environments inside as well as outside the country, the domestic companies try to leverage upon there expanded field force. Another interesting feature about this sector is that top 10 Pharma firms hold even less than $50 \%$ of the market share and making the conditions worse, the implementation of ' National Pharmaceutical Pricing Policy 2012' (NPPP) by GOI (Government of India) has resulted in margin erosion from $20 \%$ and $10 \%$ to $16 \%$ and $8 \%$ for retailers and stockists respectively. This has reduced the interest of these distribution channel members in the distribution of pharmaceutical products. Further, a uniform code for sales and marketing practices and compulsory licensing has made promotion tougher and competition intense in this sector. Although the industry reviews seem very positive for Indian Pharmaceutical market but the domestic market scenario is not as rosy a picture as it may seem to an outsider. In a development in July 2012, a joint meeting of IPA(Indian Pharmaceutical Alliance), OPPI( organization of pharmaceutical producers of India), IDMA( Indian drug manufacturers association), the Indian Pharma companies have agreed in principle to enforce a code that will restrict them from offering gifts or other sops to doctors(PTI,July 2012).

Both NPPP \& Pharmaceutical marketing code regulations have been enforced due to the fact that competitive pressure in the domestic formulation market has been rising steadily for sometime due to increase in marketing efforts by domestic players. MNCs have renewed their focus in India, smaller players contribute by offering huge discount incentives to the distribution network and doctors.(pharmaceutical industry update 2012). Moreover Pharma marketing falls under the ambit of certain regulations. Under the existing system wherein the Pharma products cannot be advertised and Pharma companies cannot directly or indirectly sponsor travel, entertainment, and hospitality for medical practitioners and their families.(Kolhatkar, Inamdar 2012). Till 2012 the Prescription generation from the customers (doctors) was primarily based on the sales efforts exerted by the field force of the company along with the sales promotion efforts exerted at the distributor end.(Sagar \& Kalaskar, 2012) but due to intense competition at present and an expected, further intensification of the same in near future, with MNCs turning their prime focus, in India, the survival of the fittest and smartest marketer will come into play.Export markets will surely become lucrative in near future, for Indian Pharmaceutical companies but considering the trends of the Indian Pharma market, it will be fruitful for the companies to focus upon and consolidate their market share in their home market first of all and then start looking for greener pastures outside.(Indian Pharma summit 2015)

\section{CUSTOMER RELATIONSHIP viz.-a-viz. APPLICATION IN PHARMACEUTICAL INDUSTRY}

Customer relationship management (CRM) is the strategic process of shaping the interactions between a company and its customers with the goal of maximizing current and lifetime value of customers for the company as well as maximizing, satisfaction for customers. CRM is a complex set of activities that together form the basis for a sustainable and hard-to-imitate competitive advantage because it involves vital customer-focused strategies. Foundation of CRM in the pharmaceutical industry is based on the prescribers (i.e. doctor) and sales force relationship. Pharmaceutical firms spend a large amount of money on marketing communication directed towards physicians. Traditionally, salespeople in the pharmaceutical industry have been held accountable for short-term revenue generation to achieve higher sales volumes. However, due to the entry of more players in the market over the last decade, the matrix of success for pharmaceutical marketing has shifted perceptibly from customer revenue to customer profitability. Pharmaceutical companies rely on sales/medical representatives to deliver marketing messages to the Doctors. A sales/medical representative prepares a customer list (of doctors) in his or her sales territory and prepare their call plans for the day/week/month in accordance with this customer list. 
These representatives often do not enlist into the call plan, those doctors who do not prescribe their products, and devote extra time and effort on doctors who are most responsive to their products. If armed with the right information, a representative can call on doctors according to their likelihood of responding to specific brands, and can carry out detailing and sampling of specific brands resulting in higher customer profitability. Pharmaceutical companies are gradually realizing that they can no longer afford to be only product or market focused. Hence they have to focus now on customer relationship management (CRM) and gain a complete understanding of their current and potential customers. Companies, which implement CRM, not only increase the efficiency of their sales and marketing efforts, but also enhance their customer's experience and loyalty towards the pharmaceutical company. Some additional challenges that pharmaceutical companies in India are facing, includes: (i) Patients influencing doctors prescriptions (ii) Cost-effectiveness of the brand of drugs; (iii) Guarding against unethical dispensing of medicines at chemists level, which bypass the physicians decision on specific brand of drugs (thereby defeating the whole purpose of the efforts done by the Pharma marketers). Critical decisions concerning strategy and resource allocation necessitate a detailed and accurate understanding of customers and overall market. By using successful sales and service strategies, pharmaceutical company could maximize customer profitability, improve marketing campaign effectiveness, and optimize multi-channel interactions with customers, resulting in higher revenue and a competitive advantage. The road map to profitability for pharmaceutical companies has been changing. Never before has the industry faced so many challenges at once. Harder-to-find blockbuster molecules, expiring patents, need to research for money making drugs, pricing pressure from all players, and competition from new drugs, me-too drug and generics are all threatening industry profitability. In addition, issues such as: strict industry and government regulations, Drug Price Control Order (DPCO), increasing media and public scrutiny coupled with prescribing decision-makers inaccessibility ( (viz: doctors who have less time to spend with the Pharma firm's sales force) require more resources from companies just to maintain status- quo ' and all this has made it difficult to achieve the firms profitability. The pharmaceutical landscape has, therefore, become more volatile and unpredictable. While these firms have to bear the soaring costs of Research and development, the purchasing power vested with few customers coupled with stringent regulations have made the promotional efforts more challenging. Today, the Pharma companies are forced to control spending on doctors. CRM helps Pharma companies to generate revenue from shelf life by reaching more new prescribers (doctors) and patients (end customer) thereby keeping them loyal by increasing their well being. Finally it is the Pharma CRM strategy that provides base for new product innovations which provides competitive advantage to these firms, to continue to thrive in the market and grow. CRM is essential for Pharmaceutical and life sciences companies- with products ranging from Low involvement products to critical, high involvement products, the type of relationships between the companies, their channels, doctors and end customers are quite unique. It is a relationship built on trust and delivery.

\section{EFFECTS OF PHARMACEUTICAL CRM ON THE PRESCRIPTION GENERATION FROM DOCTORS}

Foundation of CRM in the pharmaceutical industry is based on the prescribers (i.e. doctor) and sales force relationship. Pharmaceutical firms spend a large amount of money on marketing communication directed towards physicians. For example, the firm spent $\$ 8.5$ billion on marketing communication( Padhy \& Patnaik, 2008) directed at physicians (Wittink, 2002, Neslin, 2001) in the year 2000. Out of the above expenditure, the major head was under the detailing budget that included personal sales calls on physicians. Since detailing is a personal interaction between a physician and the firms representatives, the budget allocated are spent at the individual physician level for generating Long-term prescriptions for patients (Morelli and Konigsberg, 1992). Researchers (Narayanan, Manchand and Chintagunta, 2005) have also argued that such marketing efforts made by the firms may have both informative (e.g. reducing cognitive uncertainty) and a persuasive (e.g. inducing positive affect roles). The most useful research in this direction is probably the sparse literature in medicine that examines the motives of physicians while dispensing free samples to the patients. Such motives could emanate from factors such as: (1) financial 
savings; (2) convenience; (3) immediate initiation of therapy (4) demonstrating appropriate use of drugs; (5) adjustment of doses; (6) evaluating effectiveness of adverse effects of drugs (Chew, et al., 2000; Duffy and Clark, 2003) Studies (Gönül et al., 2001) have revealed that detailing has a positive and significant effect on doctors prescription of specific brand of drugs. Others find that detailing has a very modest effect (Mizik and Jacobson, 2004) or no effect at all (Rosenthal et al., 2003) on brand prescriptions or sales( Leeflang et al., 2004) pointed that the incongruent effects of detailing are mainly due to the marketing expenditure made by the firms across different brands. Promotion of brands would vary in accordance with Physicians preference and responsiveness of the marketers to promote them through detailing, frequent meeting or by using other promotional instruments.Though marketing efforts by pharmaceutical companies have positively affected the physicians. Prescriptions, diminishing returns to detailing have also been frequently reported (Manchanda, Rossi and Chintagunta 2004) found that product detailing had positive effects on prescription behavior of high-volume physicians, while the low-volume physician were found to be more attentive and responsive towards detailing. Researches in the past also revealed that Detailing (30.6 percent) and sampling (50.6 percent) to physicians amount to 81 percent of promotion spending by pharmaceutical firms in 2000 (Rosenthal et. al., 2003). When the firm promotes a more effective drug, as compared to a less effective drug, its ability to lower physician uncertainty about the drug and increase physicians affect toward the drug is higher, and there will be stronger scientific evidence to back up the marketing effort (Azoulay, 2002 and Narayana, Manchanda 2006) argued that a physician may financially subsidize low income or low-coverage patients through sample-dispensing and the prescribed drug is administered as a free sample. 


\section{RESEARCH REVIEWS OF SOME SELECTED RESEARCH PAPERS}

Title of the Paper : Self-Medication, Doctor \& Marketing

\begin{tabular}{|c|c|c|c|c|}
\hline Year & Author & $\begin{array}{l}\text { Factors/variables } \\
\text { studied }\end{array}$ & Sample size & $\begin{array}{l}\text { Tools/ } \\
\text { Technique adopted }\end{array}$ \\
\hline 2010 & $\begin{array}{l}\text { Rajesh Uttam } \\
\text { Kanthe }\end{array}$ & $\begin{array}{l}\text { I) attitude of doctors } \\
\text { towards OTC products in } \\
\text { comparison to prescribed } \\
\text { products. } \\
\text { II) Understand the } \\
\text { physicians behaviour \& } \\
\text { influence of various } \\
\text { promotional schemes } \\
\text { III) effectiveness of sales } \\
\text { promotional tools. }\end{array}$ & 200 physicians & $\begin{array}{l}\text { Questionnaire survey } \\
\text { used for data collection. } \\
\text { Data analyzed using } \\
\text { percentage method }\end{array}$ \\
\hline \multicolumn{5}{|c|}{$\begin{array}{l}\text { Findings of the study: A detailing visit lasts for five to ten minutes and an MR discusses about the } \\
\text { drug's composition, therapeutic value, proper dosage and potential side effects etc. Are } \\
\text { communicated. The findings of the study reveal that the effects of detailing and sampling differ } \\
\text { across drugs, however one important observation noticed was that the marketing activities on } \\
\text { physicians prescribing behaviour ranged from very small to modest for each of the drugs studied. } \\
\text { For the three drugs studied, results indicated that it took an average } 1 \text { to } 10 \text { more visits after first } \\
\text { visit by the MR, to induce new prescription. It took } 20-73 \text { additional samples to induce one new } \\
\text { prescription. Physicians are not easy targets readily persuaded by MRs but rather are tough sells as } \\
\text { evidenced by the minimal influence of sales activities on their prescribing behaviour. The major } \\
\text { reason for the limited effect of MRs is that the physicians know that they have other sources of } \\
\text { information, such as scientific papers, advice from colleagues and a physicians own training and } \\
\text { experience and according to majority of Physicians these sources are far more reliable and } \\
\text { trustworthy than MRs. Many physicians even held negative attitudes towards MRs, they feel that } \\
\text { the information given by them is biased towards the promoted drug and is unlikely to be objective } \\
\text { or even accurate. }\end{array}$} \\
\hline
\end{tabular}


Title of the Paper : A Cluster Analysis of Physician's Values, Prescribing Behaviour and Attitudes towards Firm's Marketing Communications.

\begin{tabular}{|c|c|c|c|c|}
\hline Year & Author & Factors/variables studied & Sample size & $\begin{array}{l}\text { Tools/ } \\
\text { Technique adopted }\end{array}$ \\
\hline 2011 & $\begin{array}{l}\text { Despina } \\
\text { Karayanni }\end{array}$ & $\begin{array}{l}\text { An exploratory research } \\
\text { study that tries to establish } \\
\text { associations between } \\
\text { physician's personal values } \\
\text { with his/her prescribing } \\
\text { criteria and preferred } \\
\text { marketing communication }\end{array}$ & $\begin{array}{l}69 \\
\text { physicians }\end{array}$ & $\begin{array}{l}\text { Questionnaire method adopted to } \\
\text { collect primary data. The sample } \\
\text { of } 69 \text { physicians were divided \& } \\
\text { then studied under three clusters: } \\
\text { brand ;'loyals', 'Moodies' and } \\
\text { 'bohemians '. Then a series of } \\
\text { ANOVA and TUKEY tests were } \\
\text { applied to these clusters. }\end{array}$ \\
\hline
\end{tabular}

Findings of the study: The researcher was able to find out meaningful differences among the three clusters. The Brand Loyals- have the greatest possibility among all three clusters to prescribe a branded over a generic medicine. They are more responsive to firm's promotional activities. Moodies- most probable among the three clusters to prescribe a generic medicine over non-branded ones. They show least interest among the clusters towards the marketing communication efforts of Pharma firms. Bohemians- don't discriminate between branded \& generic medicines show maximum interest towards the promotional efforts especially detailing by MRs, of Pharma firms. There are three aspects to a Pharmaceutical company's marketing communication. Viz. Direct to consumer communication, Company- Customer (physician) communication, Detailer(MR)-physician communication. According to the researcher Physicians prescribing behaviour is a hybrid buying situation because it lies in between the industrial and consumer buying situation because just like industrial buying situation, the product/brand to be purchased/prescribed is decided by a person (Physician/doctor) other than the buyer/user (patient) yet the choice of medicine to be prescribed primarily depend upon scientific criteria, however personal and social values (of the prescriber) may play a role, especially when it is about diseases that may be treated by a few alternative medicines with negligible differences. Physicians take into account a number of factors such as: price sensitivity for the drugs before prescribing it to the patient. Patient's psychological reaction to the product such as use or efficacy that may mediate the Physician's prescribing behaviour. Firm's marketing communication mix that includes detailing, sales promotion \& publicity. Physician's personal values may also be associated with their prescription and their attitudes towards complementary and marketing communication means. 
Title of the Paper : Doctor's Expectations from Pharmaceutical Companies: Which will Influence Their Prescription Behaviour

\begin{tabular}{|c|c|c|c|c|}
\hline Year & Author & $\begin{array}{c}\text { Factors/variables } \\
\text { studied }\end{array}$ & $\begin{array}{l}\text { Sample } \\
\text { size }\end{array}$ & $\begin{array}{c}\text { Tools/ } \\
\text { Technique adopted }\end{array}$ \\
\hline 2012 & $\begin{array}{l}\text { Dr. Kolhatkar } \\
\text { J malhar } \\
\text { Inamdar S } \\
\text { Irfan. }\end{array}$ & $\begin{array}{l}11 \text { attributes of } \\
\text { pharmaceutical } \\
\text { companies were } \\
\text { selected which was } \\
\text { reduced to } 4 \text { factors } \\
\text { for the purpose of } \\
\text { study. }\end{array}$ & $\begin{array}{c}116 \\
\text { Doctors } \\
\text { (Physicians } \\
\& \\
\text { consultants) }\end{array}$ & $\begin{array}{l}\text { Questionnaire method adopted to } \\
\text { collect primary data. Data Tabulation } \\
\text { method used to interpret } \& \text { analyze } \\
\text { and results have been derived by } \\
\text { factor analysis with principal } \\
\text { component analysis method so as to } \\
\text { reduce } 11 \text { factors to } 4 \text { because these } \\
\text { four factors account for } 70.43 \% \text { of } \\
\text { total variances. These factors have } \\
\text { been identified by using varimax with } \\
\text { Kaiser normalization technique. }\end{array}$ \\
\hline
\end{tabular}

Findings of the study: The biggest challenge faced by the Indian Pharmaceutical industry (IPL) lies in reinventing communication. MR is not only the face of the company but also creates an impact on the prescriber i.e. Physician/doctor. In pharmaceutical marketing, communication is most important part and main objective is to make an impression, an impression which is long lasting. In order to achieve good relationship/bonding with the customers (doctors), it is important for the Pharma companies to understand their desire and give them exactly what they want in terms of knowledge, communication and updates on recent innovations. The four major factors effecting the physicians prescribing behaviour identified by the study are: 'Knowledge updating sponsorship '- this factor is perceived to be the most important factor with highest explained variance of $22.02 \%$. 4/11 variables load on significantly to this factor. This includes literature updates, CMEs, Journal etc. This factor influences the doctors most while prescribing products of a particular company. 'Scientific Information updates support '- has second highest explained variance of $18.229 \%$. 3/11 variables load on significantly to this factor. It includes scientific updates on medicine, diseases, molecules, researches etc. 'Promotional Inputs' - this factor receives $3^{\text {rd }}$ highest explained variance of $17.180 \%, 3 / 11$ variables load on significant to this factor. It includes brand reminders,samples, gifts etc. ' Reputation of company'- factor 4 has a variance of $13.010 \%$. Although less but doctors do give some importance to company image, stock exchange position etc. Doctors tend to prescribe the brands of a reputed company. This assures quality and availability too. 
Title of the Paper : A Study of Psycho Social Factors on Doctors Prescribing Behaviour An Empirical Study in India

\begin{tabular}{|c|c|c|c|c|}
\hline Year & Author & $\begin{array}{l}\text { Factors/variables } \\
\text { studied }\end{array}$ & Sample size & Tools/ Technique adopted \\
\hline 2013 & $\begin{array}{l}\text { Dr.Neeti } \\
\text { Kasliwal }\end{array}$ & $\begin{array}{l}\text { Prescription } \\
\text { behaviour of the } \\
\text { doctors (males \& } \\
\text { females) and the } \\
\text { level of importance } \\
\text { given to the psycho } \\
\text { social factors (like } \\
\text { MRs product } \\
\text { knowledge and MR as } \\
\text { a source of } \\
\text { information of new } \\
\text { drugs ) across } \\
\text { different specialities } \\
\text { of doctors before } \\
\text { making their } \\
\text { prescription choices. }\end{array}$ & $\begin{array}{l}750 \text { doctors of } \\
\text { five different } \\
\text { specialities } \\
\text { namely, General } \\
\text { Medicine, } \\
\text { Gynecology, } \\
\text { Pediatrics, } \\
\text { Ophthalmology } \\
\text { and Psychiatry. } \\
\text { Response was } \\
\text { generated from } \\
\text { 431 doctors. }\end{array}$ & $\begin{array}{l}\text { A questionnaire was formulated } \\
\text { and pretested for reliability and } \\
\text { validity and necessary changes } \\
\text { were incorporated to formulate } \\
\text { a standardized questionnaire } \\
\text { using Likert Scale. The } \\
\text { statistical tools used were } \\
\text { frequency distribution, ANOVA } \\
\text { and Z-test for analysis }\end{array}$ \\
\hline
\end{tabular}

Findings of the study: The results \& findings of the study reveal that the Pediatricians rated psycho social (non medical) factors as least important factors influencing prescribing as compared to other specialties. Moreover senior doctors between the age group of 40-45 years, who are looked upon as KOL (key opinion leaders) to make rational prescribing decisions based on clinical facts, also rated these psycho social factors as less influencing as compared to younger doctors. The importance attached to the psycho social factors while prescribing a drug has been less on different specialties of doctors except in case of Psychiatrists who rated high importance to MRs personality traits in their prescription choices, Ophthalmologists who rated colleagues as a source of information of new drugs as more important factor as compared to other specialties and Gyanecologists who considered MR as a source of information of new drugs, as important factor which is contrary to prior studies where MRs information is perceived by doctors as untrue and inaccurate. The importance attached to the psycho social factors on prescribing behaviour of male doctors was found to be less as compared to female doctors. 
Title of the Paper : Pharmaceutical Marketing Mix Strategy and Physician's Prescription Behavior

\begin{tabular}{|l|l|l|l|l|}
\hline Year & Author & Factors/variables studied & Sample size & Tools/ \\
Technique adopted
\end{tabular}

Findings of the study: the study reveals that in pharmaceutical industry two chains run parallel to each other, the process starts with the product chain wherein a new drug formulation/molecule is developed, approved and tested in clinical trials. This chain is followed by prescription chain wherein the product is promoted to doctor's who after thorough validation prescribe it to patients who in turn purchase it from chemist (retailer). Both these chains are linked to the core marketing objective. The results obtained from the survey indicate that there is no system in Pakistan to control the marketing activities and promotional tools opted by health care professionals as well as the companies. Globally, including India and Pakistan the old trend of keeping aside $15-20 \%$ of the product budget for salesperson salaries is changing. It has been substituted with significant reduction in fixed cost that is occurring in terms of compensation to the field force. Trend is towards digitization of promotion in pharmaceutical field. The key factors for success in Pharma market as identified by the researcher is, field force skills enhancement and right kind of strategies. The researcher identifies field force optimization as the need of the hour. According to the study internet based marketing, e-detailing, sales optimization and sales analytical software can change the dimensions of sales in Pharma. The study also points out that if MRs have established good relations with Physicians, there are more chances of Doctors prescription for the promoted certain drug/brand. The data analysis points out that there is a correlation of these variables with the subject of the study i.e. factors influencing the prescribing behavior of the physician. The data shows the significance level of individual independent variable such as Promotional tools. The results of Multiple Regression Analysis (MRA) indicate that independent variables have significant relationship with dependent variable. Thereby indicating that Promotional tools like : Literature, Samples, Detailing Knowledge \& skills of Medical Reps,Activities like RTD`s, LSP \& FSP, CME`s all influence the physician's prescription behavior. 


\section{CONCLUSION}

The literature review done so far indicates that on an average a Medical representative (MR) makes only two quality calls per day, physicians feel that MRs are more aggressive and less experienced today than they were in the past. Very few doctors remember the brands promoted by MRs, according to docs the main role of an MR is to provide useful practical information to doctors and generate prescription for the products promoted by them moreover doctors can get trustworthy and relevant information from other sources such as online options, symposiums, seminars, colleagues etc. Therefore they don't have to rely on MRs for it. Researchers have suggested that MRs are not to be phased out completely by Pharma firms but there number can be easily reduced and they should be replaced by people called MSL/MSR i.e. Medical Science Liaison or Medical science Representatives. These are suppose to be those Pharma representatives that keep them informed, protect them from prescribing the wrong drug, someone who talks like them and is like another health professional and not a pushy sales representative. Some researches indicate that promotional activities, positively influence the prescription behaviour of doctors but it is rather more important to develop and maintain relationship with customers (doctors) by continuously engaging and giving them constant reminder about the brands. A healthy and long term relation can last if doctor is engaged with the MRs through continuous sharing of knowledge and helping them to counsel and aid the patients wherever possible. Some research papers also suggest that MRs, while meeting the doctors for the first time should try to trace the doctor's psycho graphic traits, in order to adapt his/her communication efforts to the doctor's typology.

As far as applications of CRM solutions to the Pharma marketing is concerned, researches indicate that Ideal' CRM solution is not always feasible and CRM has over promised and under delivered benefits to its practitioners. A well designed customer- centric CRM system, helps the Pharma firms in establishing a single view of the customer and in turn present a single face to the customer and develop a meaningful customer segmentation and customizing and differentiating customer communications based on the insights extracted from segmented data. It will help Pharma firm to create a sustainable competitive advantage in this highly competitive market, if they are able to perform and manage it well and better than others. The doctors give importance to knowledge and prefer to prescribe products/brands of those Pharma companies which help them to keep themselves updated with scientific and medical knowledge. Promotional efforts just prove to be 'an icing on the cake'.

All in all it can be concluded that prescribing behaviour of doctors is a complex activity involving interplay of number of factors which varies from marketing, relationship \& CRM strategies adopted by Pharmaceutical companies to medical \& psycho social factors which are also rated as an important criteria in the doctors decision to prescribe. The psycho social factors varies across different demographic characteristics of the doctors and the young doctors are more influenced by them as compared to the senior doctors \& among all specialities of doctors, gyanecologists are more receptive towards the information given by the MRs.

\section{REFERENCES}

Ahmed Raheem Rizwan, 'Pharmaceutical Marketing Mix Strategy and Physician's Prescription Behaviour', The Pharma innovation journal ,3(7),2014,8-12

Azoulay, Pierre, 'Do Pharmaceutical Sales Respond to Scientific Evidence?', Journal of Economics and Management Strategy, 11(4), 2002,551-559.

Banks JW, Mainous AG, 'Attitudes of Medical School Faculty', Academic Medicine. 67(9),1992, $610-12$ 
Bernstein Mitch, 'Balancing Idealistic Vs. Realistic CRM Processes ', Pharma marketing news , 2(10), 2004, 1-3

Bruche G, 'Emerging Indian Pharma Multinationals: Latecomers Catch-Up Strategies in a Globalized High Tech Industry', European Journal Of International Management, 2012, 1-23

Candill TS, Johnson MS, Rich EC, Mc Kinney WP, 'Physicians,Pharmaceutical Sales Respresentatives, and the Cost of Prescribing', Arch Family Medicine, 5, 1996, 201-206

Chandran Sanjeev, Roy Archana, Jain Lokesh, 'Implications of New Patent Regime on Indian Pharmaceutical Industry: Challenges and Opportunities ', Journal of Intellectual Property Rights, 10, 2005,269- 280

Chew, Lisa D., O.Young, Theresa S., Thomas, K. Hazlet, Katharine, A., Bradley, Charles Maynard, and Lessler, Daniel S. , 'A Physician Survey of the Effect of Drug Sample Availability on Physicians. Behaviour ', Journal of General Internal Medicine, 15,2000, 478-483

Duffy, C.M. and Clark, M., 'Who Receives Free Sample Medications?'.Journal of General Internal Medicine, 18, 2003, 205.

Girdharwal Nitin, 'A Study of Physicians Behaviour Towards Marketing of Pharmaceutical Products: A Case Study of Indian Market', Pharma info.net, November 2001, accessed in November 2013

Gönül, Füsun F., Carter, Franklin, Petrova, Elina and Srinivasan, Kannan , 'Promotion of Prescription Drugs and Its Impact on Physicians Choice Behaviour ',.Journal of Marketing,65, 2001,79-90.

Kante Uttam Rajesh, 'Self-Medication, Doctor and Marketing of OTC Products ', Asian journal of management research, $2010,229-238$

Karayanni Despina., 'A cluster Analysis of Physician's values, prescribing behaviour and attitudes towards Firm's marketing communications ', International journal of customer relationship marketing and management, 1(4),2010,62-79

Kolhatkar Jayant Malhar, Inamdar Sharfoddin Irfan, 'Doctor's Expectations from Pharmaceutical Companies: Which will Influence their Prescription Behavior ', International journal of Business management tomorrow, 2(1), 2012, 1-6

Kasliwal Neeti. , 'A Study of Psycho Social Factors on Doctors Prescribing Behaviour - An Empirical Study in India ', IOSR Journal of business and Management, 13(2), 2013, 5-10

Leeflang, Peter, Wieringa, Jaap and Wittink, Dick, 'The Effects of Pharmaceutical Marketing on Sales of Prescription Drugs in the Netherlands ',. 6th CU-Boulder Invitational Choice Symposium, 2004.

Mack John. , 'Are Sales Reps Necessary ', Pharma marketing news, 6(1),2007, 2-6

Manchanda, Puneet, Rossi, Peter E. and Chintagunta, Pradeep K. , 'Response Modeling with Non-random Marketing-Mix Variables ',. Journal of Marketing Research, 41, 2004,467-478.

Mizik, Natalie and Jacobson, Robert, 'Are Physicians .Easy Marks.? Quantifying the Effects of Detailing and Sampling on New Prescriptions ',Journal of Management Science, 50(12), 2004,1704-1715.

Morelli, D. and Koenigsberg, M.R., 'Sample Medication Dispensing in a Residency Practice ', Journal of Family Practice, 34, 1992, 42-48. 
Narendran Roshni, Narendranathan M, 'Influence of Pharmaceutical Marketing on Prescription Practices of Physicians ', university of Wollongong, Research online, Faculty of Business- papers, 2013,1-14

Narayanan, Sridhar, Manchanda, Puneet, 'Heterogeneous Learning and the Targeting of Marketing Communication for New Products '. Working paper, Graduate School of Business, Stanford University, 2006

Narayanan, Sridhar, Manchanda, Puneet and Chintagunta, Pradeep, 'Temporal Differences in the Role of Marketing Communication in New Product Categories ', Journal of Marketing Research, 42, 2005,278-290.

Neslin, Scott , 'ROI Analysis of Pharmaceutical Promotion ', Association of Medical Publications available at http://www.rappstudy.org, 2001

Padhy K. Prasanta, Patnaik Suresh, 'Implementation of Right CRM Strategy for Pharmaceutical Industry', Delhi Business Review 9( 2) 2008,39-46

Proseer H, Walley T, 'Understanding why GPs see Pharmaceutical Representatives: A Quantitative Interview study', British Journal of General Practice, 53,2003, 305-311

Rosenthal, Meredith B., Berndt, Ernst R., Donohue, Julie M., Epstein, Arnold M. and Frank, Richard G., 'Demand Effects of Recent Changes in Prescription Drug Information', Frontiers in Health Policy Research, 6, 2003, 1-26

Sagar P.N., Kalaskar B. Prashant., 'Effective Marketing Strategies Make All the Difference: A study with reference to Mankind Pharma ', International Journal of Business and Management tomorrow, 2(4), 2012,1-6

Shah Viral, 'Evolution of Pharmaceutical Industry : A global Indian \& Gujarat perspective', Journal of Pharmaceutical science and Bio scientific Research, 2(5), 2012, 219-229

Taneja Girish, 'Impact of Pharmaceutical Industry Promotion Mix on Doctors Prescribing Behaviour', Asia-Pacific Business review,4,2008,13-18

Waheeb Abdul Kareem, Jaleel Mohammed, Laeequddin Mohammad, 'Prescription Loyalty Behaviour of Physicians: An Empirical Study in India ', International Journal of pharmaceutical and Health care marketing, 5(4),2007,279-298

Wittink, D.R., 'Analysis of ROI for Pharmaceutical Promotions ',Association of Medical Publications, available at http://www.rappstudy.org, 2002

\section{Web References:}

'CRM proves essential for Pharmaceuticals \& life science', Source: www.CRM infoline.com, accessed on $17^{\text {th }}$ June 2013 at 5: $55 \mathrm{pm}$

D Souza Ajay, Future of Indian Pharma lies beyond generics", web.thehindu.com/news by industry, April $22,2012$.

Indian Pharmaceutical sector Industry update, March 2012. www.icra.in

'India Pharma Inc. Changing landscape of the Indian Pharma industry ', CII Pharma Summit 2013, www.pwc.in 
Pharmaceutical industry agrees to enforcement of marketing code: IPA. http://www.economictimes.com/news by industry. PTI July 18, 2012.

'Policy landscape Reforms for strengthening Indian pharmaceutical Industry , India PharmaSummit2014-15,23 ${ }^{\text {rd }}$ March ,www.pharmaceuticals.gov.in/gallery/India-Pharma-summit-2014-15

Sharma Shashi ., "New Patent Regime in India: Challenges and future of the Pharmaceutical industry", http://works.bepress.com/shashi_sharma/4, September 2007 